\title{
Sağlık Çalışanlarının Nargile İçme Profilleri, Nargilenin Sağlığa Olan Etkilerine Yönelik Algıları ve Sağlıklı Yaşam Biçimi Davranışları
}

\author{
Hookah Profiles, Their Perception Towards Effects of Hookah Use on \\ Health and Healthy Life Style Behaviors of Healthcare Professionals
}

\author{
Merve Topcu 1(D), Semra Zorlu 2(iD) \\ 1. Uzman Hemșire, Sivas \\ 2. Sivas Cumhuriyet Üniversitesi, Sağlık Bilimleri Fakültesi, Hemşirelik Bölümü, Halk Sağlığı Hemşireliği Anabilim Dalı, Sivas
}

\section{Abstract}

Objective: The aim of this study is to determine hookah smoking profiles of health personnels, perceptions of health effects of hookah and healthy lifestyle behaviors.

Method: The study was conducted on 526 health personnels including physicians, nurses and midwives working in three different hospitals. Data of study were collected through Personal Information Form, Perception Scale Effects of Hookah use on Health (PSEHH), Healthy Lifestyle Behaviors Scale (HLBS).

Results: The use of hookah was found to be $46.2 \%$ in male health personnels and $53.8 \%$ in female health personnels. It has been revealed that there is a positive significant relationship between mean scores of PSEHH and HLBS, and with the increase in the perception effects of hookah on health, healthy lifestyle behaviors increase. It was determined that being a male health worker increased probability of hookah smoking by 2.247 times, being still smoking increased 1.507 times.

Conclusion: Health personnels with higher perceptions health effects of hookah show healthy lifestyle behaviors more. In order to increase the awareness of health personnels regarding hookah use, it is recommended that tobacco addiction, its roles and responsibilities in tobacco control should be adequately covered in vocational education curricula.

Keywords: Health personnel, hookah smoking, perception, healthy lifestyle, nursing

Öz

Amaç: Çalışmanın amacı, sağlık çalışanlarının nargile içme profilleri, nargilenin sağlığa olan etkilerine yönelik algıları ve sağlıklı yaşam biçimi davranışlarını belirlemektir.

Yöntem: Çalışma, üç farklı hastanede görev yapmakta olan hekim, hemşire ve ebe olmak üzere 526 sağık çalışanı üzerinde yapılmıştır. Araştırmanın verileri Kişisel Bilgi Formu, Nargilenin Sağlığa Etkileri Algı Ölçeği (NSEAÖ) ve Sağıkı Yaşam Biçimi Davranışları Ölçeği (SYBDÖ) aracilığılla toplanmışıır.

Bulgular: Araştırmada nargile kullanımının erkek sağık çalışanlarında \%46.2, kadın sağlık çalışanlarında ise \%53.8 oranında olduğu bulunmuştur. NSEAÖ ile SYBDÖ puan ortalamaları arasında pozitif yönde anlamlı bir ilişki olduğu, nargilenin sağlığa etkileri algısının yükselmesiyle, sağlıkı yaşam biçimi davranışlarıın artığı ortaya çıkmışıır. Nargile içme olasılıklarını, erkek sağlık çalışanı olmanın 2.247 kat, halen sigara içiyor olmanın 1.507 kat artırdığı belirlenmiştir.

Sonuç: Nargilenin sağlığa etkileri algıları daha yüksek olan sağık çalışanlarının sağlıklı yaşam biçimi davranışlarını daha fazla gösterdiği tespit edilmiştir. Nargile kullanımına yönelik sağlık çalışanlarının bilinç ve farkındalıklarını artırmak için mesleki eğitim müfredatlarında tütün bağımlılığı ve tütün kontrolündeki rol ve sorumlulukları konusuna yeterince yer verilmesi önerilmektedir.

Anahtar kelimeler: Sağlık personeli, nargile içme, algı, sağlıklı yaşam biçimi, hemşirelik 


\section{Giriş}

Önlenebilir ölüm nedenlerinin başında gelen tütün kullanımı nedeniyle her yll yaklaşık 7 milyon insan yaşamını kaybetmektedir (1). Tütün ve tütün ürünleri kullanmanın insan sağlığına olan zararlarına ilişkin çok sayıda bilimsel çalışma olmakla birlikte tütün kullanımına bağlı hastalıklar ve ölümler giderek artmaktadır (2). Dünyada ve Türkiye'de en yaygın kullanılan tütün ürünü sigara olmakla birlikte nargile kullanımı da son yıllarda giderek artmaktadır (3-6). Nargile, halk sağlığı uzmanları tarafından küresel bir tütün salgını olarak nitelendirilmektedir (7).

İnsanlar lezzeti, kokusu, sosyal kabulünün yüksek olması, kolay ulaşabilme olanağı, sağlık riskleri konusundaki bilgi ve algı eksikliği gibi nedenlerle nargile kullanmaya yönelebilmektedir (8). Nargile kullanıcıları arasında sigara içenlerin çoğunluğunda olduğu gibi arada sırada kullanmanın sağlığa zararlı olmayacağına ilişkin yanlış bir algı vardır $(8,9)$. Birçok nargile kullanıcısı, nargilenin sigaraya göre daha zararsız olduğuna ve daha az bağımlıık yaptığına inanmaktadır (10). Gerçekte nargilede; karbonmonoksit, kurşun, kobalt, nikel, arsenik, krom, ağır metaller, polisiklik aromatik hidrokarbonlar gibi birçok toksik ve kanserojenik madde bulunmaktadır (11). Nargile dumanındaki zararlı maddeler sigara dumanına göre daha fazladır. Tek bir nargile içimi süresince 0.15-1.0 litre arasında duman inhale edilmekte ve nargile içicisi tarafından alınan bu duman miktarı bir sigara içiminden alınan duman miktarından 100-200 kat daha fazla olmaktadır (4-6,12-13). Nargile kullanımı; kanserler, pulmoner bozukluklar, kardiyovasküler hastalıklar gibi kronik hastalıklara zemin hazırlarken aynı zamanda tekrar kullanılabilme özelliğinin olması ve aynı ağızığın paylaşılması nedeniyle tüberküloz, herpes ve hepatit gibi bulaşıcı hastalıklara da yol açabilmektedir (1214).

Dünya genelinde günde yaklaşık yüz milyon kişinin nargile içtiği belirtilmektedir $(4,15)$. Özellikle genç yaş grubunda nargile kullanma oranının daha yüksek olduğu bildirilmektedir (16). Yapılan farklı çalışmalarda nargile kullanım sıkı̆̆ının \%11-27 arasında değiştiği belirlenmiştir $(17,18)$. Türkiye Küresel Yetişkin Tütün Araştırmasına göre yetişkin bireylerde nargile kullanım prevalansının \%2.3 (erkeklerde \%4.0, kadınlarda $\% 0.7)$ olduğu bulunmuştur (19). Türkiye'de genç yetişkin yaş olarak kabul edilen sağlık alanında okuyan üniversite öğrencilerine yönelik yapılan çalışmalarda nargile içme prevalansının \%26.9 ila \%34.0 arasında olduğu saptanmıştır (20-23). Sağlık çalışanlarına yönelik yürütülen bir çalışmada, tütün ürünleri kullananların \%38'inin nargile ve sigarayı birlikte kullandıkları bulunmuştur (24). Sağlık çalışanlarıyla yürütülen başka bir çalışmada, sigara dışında herhangi bir tütün ürünü kullananların büyük çoğunluğunun nargile kullandığı ortaya çıkmıştır (25). Yapılan bir başka çalışmada, hemşirelerin \%28.4'ünün nargile içtiği belirlenmiştir (26).

Sağlık çalışanlarının tütün ve tütün ürünlerini kullanmayarak toplumda rol modeli olmaları ve toplumdaki bireyleri sağlığa zararlı alışkanlıklar ve tütün bağımlılığı konusunda bilinçlendirmeleri gerekmektedir (27). Sağlık çalışanları arasında eğitici rolü ile ön plana çıkan hemşirelerin, son yıllarda giderek popüler olan nargile kullanımına ve genel olarak tütün bağımlıı̆ına yönelik toplumun bilinç ve farkındalığının artııımasındaki sorumlulukları fazladır (28). Sağlık çalışanlarının tütün ürünü kullanması, hem toplumun tütün ve tütün ürünlerinin zararlı olduğuna ilişkin görüş ve algılarına hem de tütün bağımlılığına yönelik sağlık çalışanları tarafından verilen eğitimlerin inandırıcıı̆̆ına zarar vermektedir. Bu nedenle sağlık çalışanlarının öncelikle kendilerinin sağ|ıkı yaşam biçimi davranışlarını benimsemeleri ve sergilemeleri, daha sonra da tüm toplumu bu konuda eğitmeleri gerekmektedir (29). Başta sağlık çalışanları tarafından sergilenmesi beklenen sağlıklı yaşam biçimi davranışları; bireyin ivilik düzeyini artırarak sağlığını geliştiren, kendini gerçekleştirmeyi sağlayan davranışlar olup bu davranışlardan birisi de tütün ve tütün ürünlerini kullanmamaktadır. Oysa literatür bulguları, sağlık çalışanlarının ve geleceğin sağık profesyonelleri olan sağllk alanında öğrenim gören öğrencilerin başta sigara ve nargile olmak üzere tütün ürünleri kullanım sıkığının azımsanmayacak oranlarda olduğunu ortaya koymaktadır (20,24-26,30-31). Hem içeriğindeki zararlı maddeler ve yol açtığı hastalıklar hem de zararsız olduğuna ya da daha az bağımlıık yaptığına ilişkin yanlış algılar nedeniyle giderek yaygınlaşan nargile kullanımı, halk sağlığı açısından önemli bir sorun olmaya devam etmektedir. Bu nedenle, sağlıksız yaşam biçimi davranışlarından biri olan nargile 
kullanımının toplumdaki yaygınlığına ve bireylerin nargileye ilişkin görüş ve algılarına yönelik araştırmalara gereksinim duyulmaktadır. Literatür bilgileri, sağlık çalışanları da dahil toplumda nargile kullanımının azımsanmayacak sıkıkta olduğunu ortaya koymaktadır $(9,18)$. Bu noktadan hareketle bu çalışma, sağlık çalışanlarının nargile içme profillerini, nargilenin sağlığa olan etkilerine yönelik algılarını ve sağıklı yaşam biçimi davranışlarını belirlemek amacıyla yapıımıştır.

\section{Yöntem}

\section{Örneklem}

Kesitsel tipte olan araştırma, Sivas il merkezinde bulunan üç farklı hastanede görev yapmakta olan hekim, hemşire ve ebe olmak üzere 526 sağlık çalışanı üzerinde yapıldı. Araştırmanın verileri 1 Kasım 2019-1 Mart 2020 tarihleri arasında toplandı. Araştırmanın evrenini il merkezindeki hastanelerde çalışan hekim, hemşire ve ebeler (2279) oluşturdu. Evrenin bilindiği $n=N t 2$ pq/(N-1)d 2 +t 2 pq formülü kullanılarak $N=$ $2279,=0.05,=0,8,=1.96,=0.8$ ile yapılan hesaplamaya göre toplam 526 sağlık çalışanı örnekleme alındı. Tabakalı örnekleme yöntemi kullanılarak her bir hastane birer tabaka olarak alındı ve toplam sağlık personelinin hastanenin toplam sağlık personeline oranı hesaplanarak her bir hastanenin evreni hesaplandı. Daha sonra her bir meslek grubu birer tabaka olarak alınmış ve meslek gruplarındaki sağlık çalışanı sayısının 0 hastanedeki tüm sağlık çalışanı sayısına oranıyla meslek gruplarının ayrı ayrı evren hesaplaması yapıldı. Her bir birimden veri toplama formları uygulanacak sağlık çalışanı basit rastgele örnekleme yöntemi ile seçildi.

\section{İşlem}

Araştırmaya başlamadan önce Sivas Cumhuriyet Üniversitesi Girişimsel Olmayan Klinik Araştırmalar Etik Kurulundan izin (karar no: 2019-10/17) ve araştırmanın yapılacağı kurumlardan (sayı no: Medicana2019/3734, Numune-93848782/799, Üniversite-93596471-774.99-E.35109 saylı) yazlı izin alındı. Araştırmaya katıım gönüllülük esasına dayandı. Araştırmaya katılan sağlık personellerinden bilgilendirilmiş onam formu ile yazılı izinleri dahilinde veriler yüz yüze görüşme tekniği ile toplandı.

Araştırmanın uygulanmasından önce, araştırmacı tarafından çalışmanın yürütüleceği hastaneler ziyaret edilerek kurum ve birim yöneticilerine araştırmanın amacı açıklandı ve veri toplama araçlarının uygulanması için izin alındı. Araştırmanın verileri 1 Kasım 2019-1 Mart 2020 tarihleri arasında toplandı. Örneklem, Sivas il merkezinde bulunan üç farklı hastanede görev yapmakta olan hekim, hemşire ve ebelerden oluşan 526 sağlık çalışanından oluştu. Araştırmacı tarafından, sırasıyla her bir hastaneye gündüz mesai saatlerinde gidildi ve basit rasgele örnekleme yöntemi ile belirlenen sağlık çalışanları çalıştıkları birimlerde ziyaret edildi. Örneklemde yer alan sağlık çalışanlarına görevlerini aksatmayacak zaman aralığı gözetilerek ve çalıştıkları birimde uygun bir odaya geçilerek araştırmanın amacı açıklandı ve bilgilendirilmiş onamları alındı. Ardından sağlık çalışanlarına yüz yüze görüşme tekniği kullanılarak veri toplama araçları verildi ve kendilerinin form ve ölçekleri doldurmaları istendi. Doldurulan formlar, araştırmacı tarafından kontrol edilerek sağlık çalışanlarından alındı. Form ve ölçeklerin doldurulması her bir sağlık çalışanı için ortalama 15-20 dakika sürdü. Araştırmada "Kişisel Bilgi Formu", "Nargilenin Sağlığa Etkileri Algı Ölçeği (NSEAÖ)" ve "Sağlıkı Yaşam Biçimi Davranışları Ölçeği (SYBDÖ)" kullanıldı.

\section{Veri Toplama Araçları}

\section{Kişisel Bilgi Formu}

Araştırmacılar tarafından literatür taranarak $(32,33)$ hazırlanan ve sağlık çalışanlarının sosyodemografik ve nargile içme davranışı ile ilgili özelliklerini sorgulayan 28 sorudan oluşan bir formdur.

\section{Nargilenin Sağlığa Etkileri Algı Ölçeği (NSEAÖ)}

Ölçek, Çakmak ve Çınar tarafından geliştirilip geçerlilik ve güvenirliği yapılmış olan ve 15 maddeden oluşan 5'li likert tipinde olan bir ölçektir (12). Her bir madde 1'den 5'e kadar puanlanmakta olup, ölçekten 
alınabilecek minimum puan 15, maksimum puan ise 75'tir. Puanın yüksek olması nargilenin sağığa etkileri ile algının iyi olduğunu göstermektedir. Çakmak ve Çınar'ın (2014) çalışmasında ölçeğin Cronbach Alpha değeri 0.93 olarak bulunmuş, bu araştırmadaki Cronbach Alpha güvenirlik katsayısı ise 0.86 olarak bulundu (12).

\section{Sağlıklı Yaşam Biçimi Davranışları Ölçeği-II (SYBDÖ)}

Bahar ve arkadaşları tarafından geçerlilik ve güvenilirliği yapılmış olan ölçek, 52 madde ve altı faktörden oluşmaktadır (32). Bu faktörler; manevi gelişim, kişilerarası ilişkiler, beslenme, fiziksel aktivite, sağlık sorumluluğu ve stres yönetimidir. Dörtlü likert tipinde olan ölçekte puanlama; hiçbir zaman (1), bazen (2), sık sık (3), düzenli olarak (4) puan şeklinde yapılmaktadır. Ölçekten alınabilecek minimum puan 52, maksimum puan 208'dir. Ölçekten alınan puanın artması, bireylerin olumlu sağlıklı yaşam biçimi davranışları geliştirdiklerini göstermektedir. Ölçeğin Türkçe'ye uyarlanan formunun Cronbach alfa güvenirlik katsayısı 0.94 olarak bulunmuştur, bu araştırmadaki Cronbach alfa güvenirlik katsayısı ise 0.90 olarak bulundu.

\section{Veri Analizi}

Araştırma kapsamında kullanılan veriler anket ve ölçek formlarıyla elde edildi. Araştırmadan elde edilen veriler SPSS (Statistical Package for Social Sciences) for Windows 22.0 programı kullanılarak analiz edildi. Veriler değerlendirilirken katılımcıların sosyo-demografik özelliklerinin tanımlayıcı istatistiksel bilgileri (sayı ve yüzde) tespit edildi. Sağlık çalışanlarının nargile içme durumları ile meslek, eğitim durumu, yaş, cinsiyet medeni durum, çocuk durumu, ekonomik durum, aile tipi ve sigara içme durumları arasındaki ilişkiye dair bulgular Ki-Kare analizi ile tespit edildi.

Sağlık çalışanlarından elde edilen verilerin normal dağılımda olup olmadığını test etmek için KolmogorovSmirnov (K-S) testi sonuçlarına bakıldı. Verilerin normal dağılımdan gelmediği belirlendi ve analizlere non parametrik testlerle devam edildi. Bağımsız iki grup için Mann Whitney U, ikiden fazla bağımsız grup için Kruskal Wallis tek yönlü varyans analizi testleri kullanıldı. Araştırmada değişkenler arasındaki ilişkiyi ortaya çıkarmak için Pearson Korelasyon ve lojistik regresyon analizi kullanıldı. Anlamlılık düzeyi $p<0.05$ olarak kabul edildi.

\section{Bulgular}

Araştırmaya katılan sağlık çalışanlarının yaş ortalaması 33.11 7.94 (Min:20; Max:66) olarak hesaplandı. Sağlık çalışanlarının \%63.9'unun 20-35 yaş arasında, \%68.4'ünün kadın, \%45.8'inin lisans mezunu, \%63.3'ünün evli, \%85'inin çekirdek aile tipine sahip ve \%60.1'inin gelirinin giderine denk olduğu tespit edildi. Sağlık çalışanlarının \%59'u hemşire olup \%46.6'sının yaşam boyu toplam 100 adet sigara içmiş olduğu ve \%32.9'unun halen sigara içtiği belirlendi. Sağlık çalışanlarının NSEAÖ'den aldıkları puan ortalamasının $66.29 \pm 7.93$ olduğu ve nargilenin sağlığa etkileri konusundaki algılarının ivi; SYBDÖ'den aldıkları puan ortalamasının $127.22 \pm 24.21$ olduğu ve sağlıkı yaşam biçimi davranışlarının orta düzeyde olduğu bulundu. NSEAÖ ile SYBDÖ-II puan ortalamaları arasında pozitif yönde anlamlı bir ilişki olduğu, sağlık çalışanlarının nargilenin sağlığa etkileri algısının yükselmesiyle, sağlıklı yaşam biçimi davranışlarının arttığı belirlendi $(p<0.05)$.

Sağlık çalışanlarının \%17.3'ünün nargile kullandığı, \%63.1'inin nargile içmeye yönelmesinde arkadaş çevresinin etkisinin olduğu, \%60.4'ünün nargileyi nargile kafelerde içtiği, \%41.8'inin beş ve üzeri yıldır nargile içtiği, \%1.7'sinin her gün nargile içtiği, \%52.7'sinin bir oturumluk nargile içme süresinin bir saatten az olduğu ve tamamının aromalı nargileyi tercih ettikleri bulundu (Tablo 1). Araştırmaya katılan sağlık çalışanlarının nargileye yönelik düşünceleri incelendiğinde; \%50.4'ünün nargileyi sigaradan daha zararlı buldukları, \%92.8'inin nargilenin zararlı olduğunu, \%60.5'inin nargilenin bağımlılık yaptığını ve \%82.1'inin nargilenin hastalık bulaştırdığını düşündüğü saptandı. Sağlık çalışanlarının \%41.6'sının sigara/ nargileyi bırakmada bireysel iradeyi en etkili yol olarak gördüğü belirlendi (Tablo 1). 
Tablo 1. Sağlık çalışanlarının nargile kullanma özellikleri ve nargileye yönelik düşünceleri $(n=526)$

\begin{tabular}{|c|c|c|}
\hline \multirow{2}{*}{\multicolumn{3}{|c|}{$\begin{array}{l}\text { Sağllk Çalışanlarının Nargile Kullanma Özellikleri } \\
\text { Naraile icme durumu }(n=526)\end{array}$}} \\
\hline & & \\
\hline \multicolumn{3}{|l|}{$\begin{array}{l}\text { Nargile içme durumu ( } n=526) \\
\text { Evet }\end{array}$} \\
\hline Hayır & 415 & 78.9 \\
\hline Bıraktım & 20 & 3.8 \\
\hline \multicolumn{3}{|l|}{ Nargileye yönelten etkenler $(n=111)$} \\
\hline Arkadaş çevresi & 70 & 63.1 \\
\hline Yenilik arayışı & 10 & 9.0 \\
\hline Ailede kullanan birinin olması & 9 & 8.1 \\
\hline En yakın üç arkadaştan en az birinin kullanması & 8 & 7.2 \\
\hline Hepsi & 10 & 9.0 \\
\hline \multicolumn{3}{|l|}{ Nargile içilen yer $(n=111)$} \\
\hline Nargile kafe & 67 & 60.4 \\
\hline Kafe & 28 & 25.2 \\
\hline Ev & 16 & 14.4 \\
\hline \multicolumn{3}{|l|}{ Nargile içen $(n=91)$} \\
\hline Erkek sağılı çalışanı & 42 & 46.2 \\
\hline Kadın sağlık çalışanı & 49 & 53.8 \\
\hline \multicolumn{3}{|l|}{ Nargile içme süresi ortalaması $3.92 \pm 1.05$ (Min:2.00; Max:6.00) yıl } \\
\hline \multicolumn{3}{|l|}{ Nargile į̧me süresi $(n=91)$} \\
\hline 2 yıl ve altı & 20 & 22.0 \\
\hline 2-4 yll arası & 33 & 36.2 \\
\hline 5 yıl ve üzeri & 38 & 41.8 \\
\hline \multicolumn{3}{|l|}{ Nargile içme sıklığı $(n=91)$} \\
\hline Her gün & 9 & 1.7 \\
\hline Haftada birkaç kez & 21 & 4.0 \\
\hline Ayda birkaç kez & 28 & 5.3 \\
\hline Yılda birkaç kez & 33 & 6.3 \\
\hline \multicolumn{3}{|l|}{ Bir oturumluk nargileyi içme süresi $(n=91)$} \\
\hline Bir saatten az & 48 & 52.7 \\
\hline Bir saat & 18 & 19.8 \\
\hline Bir saatten fazla & 25 & 27.5 \\
\hline \multicolumn{3}{|l|}{ Tercih edilen nargile türü $(n=91)$} \\
\hline Aromalı & 91 & 100.0 \\
\hline Sağlık Çalışanlarının Nargileye Yönelik Düşünceleri & Sayı & $\%$ \\
\hline \multicolumn{3}{|l|}{ Nargile ve sigaranın insan sağlığına zararları konusundaki düşüncesi } \\
\hline Nargile zararsızdır & 13 & 2.5 \\
\hline Nargile sigaradan daha az zararlıdır & 59 & 11.2 \\
\hline Eşit derecede zararlıdır & 189 & 35.9 \\
\hline Nargile daha zararlıdır & 265 & 50.4 \\
\hline \multicolumn{3}{|l|}{ Nargilenin sağlığa zararları konusundaki düşüncesi } \\
\hline Zararlıdir & 488 & 92.8 \\
\hline Zararsızdır & 7 & 1.3 \\
\hline Bilgim yok & 31 & 5.9 \\
\hline \multicolumn{3}{|l|}{ Nargile ve bağımlılık konusundaki düşüncesi } \\
\hline Nargile bağımlılık yapar & 318 & 60.5 \\
\hline Nargile bağımlılık yapmaz & 109 & 20.7 \\
\hline Bilgim yok & 99 & 18.8 \\
\hline \multicolumn{3}{|l|}{ Nargile ve bulaşıcı hastalık konusundaki düşüncesi } \\
\hline Hastalık bulaştırır & 432 & 82.1 \\
\hline Hastalık bulaştırmaz & 40 & 7.6 \\
\hline Bilgim yok & 54 & 10.3 \\
\hline \multicolumn{3}{|l|}{ Sigara/ nargileyi bırakmada tanımladıkları en etkili yol } \\
\hline Bireysel irade & 219 & 41.6 \\
\hline Profesyonel destek & 131 & 24.9 \\
\hline Çevresel faktörler & 57 & 10.9 \\
\hline llaçla bırakmak & 119 & 22.6 \\
\hline
\end{tabular}


Sağlık çalışanlarının eğitim durumları, yaşları, cinsiyetleri, medeni durumları, ekonomik durumları ve sigara içme durumları ile nargile kullanma durumları arasında anlamlı bir ilişki bulunmuş; nargile kullanımının eğitim düzeyi lisansüstü olan, 20-35 yaş arasında olan, erkek, bekâr, çocuğu olmayan, geliri giderden fazla olan ve her gün sigara içen sağlık çalışanlarında daha yüksek olduğu belirlendi $(p<0.05)$. Meslek, aile tipi ve tanısı konulmuş hastalık olma durumu ile nargile içme arasında anlamlı bir fark olmadığı saptandı (p>0.05) (Tablo 2).

Tablo 2. Sağlık çalışanlarının tanıtıcı özelliklerine göre nargile içme durumları $(n=526)$

\begin{tabular}{|c|c|c|c|c|c|c|c|c|c|c|}
\hline \multirow[t]{2}{*}{ Tanıtıcı Özellikleri } & \multicolumn{2}{|c|}{$\begin{array}{l}\text { Nargile } \\
\text { içenler }\end{array}$} & \multicolumn{2}{|c|}{$\begin{array}{c}\text { Nargile } \\
\text { içmeyenler }\end{array}$} & \multicolumn{2}{|c|}{$\begin{array}{c}\text { Bırakmış } \\
\text { olanlar }\end{array}$} & \multicolumn{2}{|c|}{ Toplam } & \multicolumn{2}{|c|}{ İstatistiksel analiz } \\
\hline & Sayı & $\%$ & Sayı & $\%$ & Sayı & $\%$ & Sayı & $\%$ & $X^{2}$ & $p$ \\
\hline \multicolumn{11}{|l|}{ Meslek } \\
\hline Hekim & 26 & 15.6 & 134 & 80.2 & 7 & 4.2 & 167 & 100 & \multirow[t]{3}{*}{3.055} & \multirow[t]{3}{*}{, 549} \\
\hline Hemşire & 60 & 19.4 & 239 & 77.1 & 11 & 3.5 & 310 & 100 & & \\
\hline Ebe & 5 & 10.2 & 42 & 85.7 & 2 & 4.1 & 49 & 100 & & \\
\hline \multicolumn{11}{|l|}{ Eğitim durumu } \\
\hline Lise & 14 & 23.3 & 41 & 68.3 & 5 & 8.3 & 60 & 100 & \multirow[t]{4}{*}{16.584} & \multirow[t]{4}{*}{, 011} \\
\hline Lisans & 33 & 13.7 & 202 & 83.8 & 6 & 2.5 & 241 & 100 & & \\
\hline Lisansüstü & 18 & 30.0 & 39 & 65.0 & 3 & 5.0 & 60 & 100 & & \\
\hline Tıpta Uzmanlık & 26 & 15.8 & 133 & 80.6 & 6 & 3.6 & 165 & 100 & & \\
\hline \multicolumn{11}{|l|}{ Yaş } \\
\hline $20-35$ yaş & 76 & 22.6 & 249 & 74.1 & 11 & 3.3 & 336 & 100 & \multirow[t]{3}{*}{19.372} & \multirow[t]{3}{*}{, 001} \\
\hline $36-50$ yaş & 14 & 7.6 & 162 & 87.6 & 9 & 4.9 & 185 & 100 & & \\
\hline 51 ve üzeri & 1 & 20.0 & 4 & 80.0 & 0 & 0 & 5 & 100 & & \\
\hline \multicolumn{11}{|l|}{ Cinsiyet } \\
\hline Kadın & 49 & 13.6 & 299 & 83.1 & 12 & 3.3 & 360 & 100 & \multirow[t]{2}{*}{12.134} & \multirow[t]{2}{*}{, 002} \\
\hline Erkek & 42 & 25.3 & 116 & 69.9 & 8 & 4.8 & 166 & 100 & & \\
\hline \multicolumn{11}{|l|}{ Medeni durum } \\
\hline Bekâr & 50 & 25.9 & 135 & 69.9 & 8 & 4.1 & 193 & 100 & \multirow[t]{2}{*}{16.241} & \multirow[t]{2}{*}{, 001} \\
\hline Evli & 41 & 12.3 & 280 & 84.1 & 12 & 3.6 & 333 & 100 & & \\
\hline \multicolumn{11}{|l|}{ Çocuk durumu } \\
\hline Çocuk yok & 48 & 25.3 & 136 & 71.6 & 6 & 3.2 & 190 & 100 & \multirow[t]{2}{*}{13.245} & \multirow[t]{2}{*}{, 001} \\
\hline Çocuk var & 43 & 12.8 & 279 & 83.0 & 14 & 4.2 & 336 & 100 & & \\
\hline \multicolumn{11}{|l|}{ Ekonomik durum } \\
\hline Gelir giderden az & 36 & 24.0 & 106 & 70.7 & 8 & 5.3 & 150 & 100 & 14.936 &, 005 \\
\hline Gelir gidere denk & 40 & 12.7 & 267 & 84.5 & 9 & 2.8 & 316 & 100 & & \\
\hline Gelir giderden fazla & 15 & 25.0 & 42 & 70.0 & 3 & 5.0 & 60 & 100 & & \\
\hline Aile tipi & & & & & & & & & & \\
\hline Çekirdek & 72 & 16.1 & 360 & 80.5 & 15 & 3.4 & 447 & 100 & 7.177 & ,127 \\
\hline Geniş & 10 & 19.6 & 38 & 74.5 & 3 & 5.9 & 51 & 100 & & \\
\hline Parçalanmış & 9 & 32.1 & 17 & 60.7 & 2 & 7.1 & 28 & 100 & & \\
\hline Sigara içme durumu & & & & & & & & & & \\
\hline Her gün içiyor & 45 & 49.5 & 95 & 22.9 & 10 & 50.0 & 150 & 100 & 46.840 & ,001 \\
\hline Ara sıra içiyor & 9 & 9.9 & 12 & 2.9 & 2 & 10.0 & 23 & 100 & & \\
\hline Sigarayı bırakmış & 2 & 2.2 & 25 & 6.0 & 1 & 5.0 & 28 & 100 & & \\
\hline Sigara içmiyor & 35 & 38.5 & 283 & 68.2 & 7 & 35.0 & 325 & 100 & & \\
\hline
\end{tabular}

$X^{2}$ : Ki Kare Testi; p: Anlamlılık düzeyi $(p<0.05)$

Sağlık çalışanlarının eğitim durumları, cinsiyetleri, medeni durumları, ekonomik durumları, aile tipleri ve tanıSı konulmuş hastalık durumları ile NSEAÖ toplam puan ortalamaları arasında anlamlı bir ilişki bulunmuş; yüksek lisans mezunu olanların diğer eğitim düzeylerine, kadın sağlık çalışanlarının erkek sağlık çalışanlarına, evli olanların bekârlara, geliri giderden fazla olanların az olanlara, geniş ailede olanların diğer aile tiplerine, tanısı konulmuş hastalığı olanların olmayanlara ve hemşirelerin diğer meslek gruplarına göre nargilenin sağlığa etkileri algılarının daha yüksek olduğu belirlendi $(p<0.05)$ (Tablo 3). 
Tablo 3. Sağılk çalışanlarının tanıtıcı özelliklerine göre NSEAÖ ve SYBDÖ puan ortalamaları

\begin{tabular}{|c|c|c|c|c|c|c|}
\hline & \multicolumn{3}{|c|}{ NSEAO } & \multicolumn{3}{|c|}{ SYBDÖ } \\
\hline Eğitim durumu & $\mathrm{X} \pm \mathrm{SS}$ & Min & $\operatorname{Max}$ & $\mathrm{X} \pm \mathrm{SS}$ & Min & Max \\
\hline Lise & $67.53 \pm 6.93$ & 50.00 & 75.00 & $124.56 \pm 27.27$ & 67.00 & 190.00 \\
\hline Lisans & $66.38 \pm 8.41$ & 35.00 & 75.00 & $129.10 \pm 23.92$ & 83.00 & 206.00 \\
\hline Y.Lisans & $68.65 \pm 6.72$ & 46.00 & 75.00 & $129.46 \pm 28.46$ & 85.00 & 199.00 \\
\hline T.Uzmanlık & $64.86 \pm 7.73$ & 45.00 & 75.00 & $124.63 \pm 21.53$ & 77.00 & 208.00 \\
\hline İstatistiksel Analiz & \multicolumn{3}{|c|}{$K W=4.124 \quad p=, 007$} & \multicolumn{3}{|c|}{$K W=1.531 \quad p=, 205$} \\
\hline \multicolumn{7}{|c|}{ Yaş ortalaması $33.11 \pm 7.94$ (Min: 20.00 ; Max:66.00) } \\
\hline \multicolumn{7}{|l|}{ Yaş } \\
\hline 20-35 yaş & $66.69 \pm 7.93$ & 35.00 & 75.00 & $128.58 \pm 25.38$ & 77.00 & 208.00 \\
\hline $36-50$ yaş & $65.57 \pm 7.99$ & 41.00 & 75.00 & $124.56 \pm 21.84$ & 67.00 & 185.00 \\
\hline $51-66$ yaş & $66.20 \pm 5.01$ & 62.00 & 73.00 & $134.40 \pm 22.19$ & 114.00 & 166.00 \\
\hline Istatistiksel Analiz & \multicolumn{3}{|c|}{$K W=1.303 \quad p=, 303$} & \multicolumn{3}{|c|}{$K W=1.878 \quad p=, 154$} \\
\hline \multicolumn{7}{|l|}{ Cinsiyet } \\
\hline Kadın & $67.19 \pm 7.12$ & 41.00 & 75.00 & $128.56 \pm 24.84$ & 83.00 & 206.00 \\
\hline Erkek & $64.35 \pm 9.19$ & 35.00 & 75.00 & $124.33 \pm 22.60$ & 67.00 & 208.00 \\
\hline İstatistiksel Analiz & \multicolumn{3}{|c|}{$M W=14.881 ; p=, 001$} & \multicolumn{3}{|c|}{$M W=3.488 ; p=, 062$} \\
\hline \multicolumn{7}{|l|}{ Medeni durum } \\
\hline Bekar & $65.11 \pm 8.79$ & 35.00 & 75.00 & $126.62 \pm 23.33$ & 77.00 & 206.00 \\
\hline Evli & $66.98 \pm 7.352$ & 41.00 & 75.00 & $127.57 \pm 24.73$ & 67.00 & 208.00 \\
\hline İstatistiksel Analiz & \multicolumn{3}{|c|}{$\mathrm{MW}=6.638 ; p=, 009$} & \multicolumn{3}{|c|}{$M W=0.191 ; p=, 662$} \\
\hline \multicolumn{7}{|l|}{ Ekonomik durum } \\
\hline Gelir giderden az & $64.82 \pm 8.90$ & 35.00 & 75.00 & $125.62 \pm 27.14$ & 67.00 & 208.00 \\
\hline Gelir gidere denk & $66.77 \pm 7.50$ & 44.00 & 75.00 & $126.72 \pm 22.16$ & 77.00 & 190.00 \\
\hline Gelir giderden fazla & $67.46 \pm 7.19$ & 45.00 & 75.00 & $133.88 \pm 26.10$ & 85.00 & 195.00 \\
\hline İstatistiksel Analiz & \multicolumn{3}{|c|}{$K W=3.862 ; p=, 022$} & \multicolumn{3}{|c|}{$K W=2.679 ; p=, 070$} \\
\hline \multicolumn{7}{|l|}{ Aile tipi } \\
\hline Çekirdek & $66.39 \pm 7.55$ & 41.00 & 75.00 & $127.85 \pm 24.22$ & 67.00 & 208.00 \\
\hline Geniş & $68.13 \pm 7.45$ & 44.00 & 75.00 & $123.58 \pm 24.65$ & 85.00 & 191.00 \\
\hline Parçalanmış & $61.35 \pm 7.93$ & 35.00 & 75.00 & $123.78 \pm 23.11$ & 88.00 & 170.00 \\
\hline İstatistiksel Analiz & \multicolumn{3}{|c|}{$K W=6.979 ; p=, 001$} & \multicolumn{3}{|c|}{$K W=5.027 ; p=, 007$} \\
\hline \multicolumn{7}{|c|}{ Tanısı konulmuş hastalık durumu } \\
\hline Hayır & $65.88 \pm 7.70$ & 41.00 & 75.00 & $125.81 \pm 23.99$ & 67.00 & 206.00 \\
\hline Evet & $68.07 \pm 8.68$ & 35.00 & 75.00 & $133.34 \pm 24.33$ & 87.00 & 209.00 \\
\hline İstatistiksel Analiz & \multicolumn{3}{|c|}{$M W=6.149 ; p=, 013$} & \multicolumn{3}{|c|}{$M W=7.880 ; p=, 005$} \\
\hline \multicolumn{7}{|l|}{ Meslek } \\
\hline Hekim & $64.74 \pm 7.69$ & 45.00 & 75.00 & $124.28 \pm 21.65$ & 77.00 & 208.00 \\
\hline Hemşire & $67.03 \pm 8.15$ & 35.00 & 75.00 & $127.32 \pm 24.86$ & 67.00 & 206.00 \\
\hline Ebe & $66.89 \pm 6.60$ & 47.00 & 75.00 & $136.65 \pm 26.27$ & 88.00 & 206.00 \\
\hline İstatistiksel Analiz & \multicolumn{3}{|c|}{$K W=4.723 ; p=, 009$} & \multicolumn{3}{|c|}{$K W=5.027 ; p=, 007$} \\
\hline
\end{tabular}

KW: Kruskal Wallis Testi; MW: Manny Whitney U Testi; SS= Standart Sapma; Min: En Küçük Değer; Max: En Yüksek Değer;

$\overline{\mathrm{X}}$ : Aritmetik Ortalama

Sağlık çalışanlarının aile tipleri, tanısı konulmuş hastalık durumları ve meslekleri ile SYBDÖ toplam puan ortalamaları arasında anlamlı bir ilişki bulundu; çekirdek aile tipine sahip olanların diğer aile tiplerine, tanısı konulmuş hastalığı olanların olmayanlara, ebelerin diğer meslek gruplarına göre sağlıklı yaşam biçimi davranışları puan ortalamalarının daha yüksek olduğu belirlendi $(p<0.05)$ (Tablo 3).

Sağlık çalışanlarının nargile kullanma durumları ile NSEAÖ ve SYBDÖ toplam puan ortalamaları arasında anlamlı bir ilişki bulundu, nargile içmeyen sağlık çalışanlarının nargile içen ve nargileyi bırakmış olan sağlık çalışanlarına göre nargilenin sağlığa etkileri algılarının daha yüksek olduğu belirlendi $(p<0.05)$. Nargile içen sağlık çalışanlarının nargile içmeyen ve nargileyi bırakmış olan sağlık çalışanlarına göre SYBDÖ toplam puan ortalamalarının daha yüksek olduğu saptandı $(p<0.05)$ (Tablo 4). 
Tablo 4. Sağlık çalışanlarının nargile kullanma özelliklerine ve nargileye yönelik düşüncelerine göre NSEAÖ ve SYBDÖ puan ortalamaları

\begin{tabular}{|c|c|c|c|c|c|c|}
\hline & \multicolumn{3}{|c|}{ NSEAÖ } & \multicolumn{3}{|c|}{ SYBDÖ } \\
\hline $\begin{array}{l}\text { Nargile kullanma } \\
\text { özellikleri }\end{array}$ & $\mathrm{X} \pm \mathrm{SS}$ & Min & Max & $\mathrm{X} \pm \mathrm{SS}$ & Min & Max \\
\hline Evet & $64.78 \pm 9.26$ & 35.00 & 75.00 & $132.08 \pm 27.40$ & 86.00 & 208.00 \\
\hline Hayır & $66.79 \pm 7.52$ & 41.00 & 75.00 & $126.52 \pm 23.54$ & 67.00 & 196.00 \\
\hline Bıraktım & $62.80 \pm 8.46$ & 45.00 & 75.00 & $119.65 \pm 19.65$ & 88.00 & 168.00 \\
\hline İstatistiksel Analiz & \multicolumn{3}{|c|}{$K W=4.484 \quad p=, 012$} & \multicolumn{3}{|c|}{$K W=3.009 \quad p=, 049$} \\
\hline \multicolumn{7}{|l|}{ Nargile içme süresi } \\
\hline 2 yıl altı & $63.40 \pm 9.39$ & 45.00 & 75.00 & $122.80 \pm 16.73$ & 86.00 & 162.00 \\
\hline $2-4$ yıl arası & $62.96 \pm 10.27$ & 35.00 & 75.00 & $130.30 \pm 27.83$ & 99.00 & 199.00 \\
\hline 5 yıl ve üzeri & $67.07 \pm 7.92$ & 50.00 & 75.00 & $138.52 \pm 30.34$ & 93.00 & 208.00 \\
\hline İstatistiksel Analiz & \multicolumn{3}{|c|}{$K W=0.968 p=, 411$} & \multicolumn{3}{|c|}{$K W=2.402 \quad p=, 069$} \\
\hline \multicolumn{7}{|l|}{ Nargile içme yeri } \\
\hline Ev & $65.18 \pm 8.74$ & 51.00 & 75.00 & $129.93 \pm 22.38$ & 95.00 & 172.00 \\
\hline Nargile kafe & $63.80 \pm 9.92$ & 35.00 & 75.00 & $128.82 \pm 28.51$ & 86.00 & 206.00 \\
\hline Kafe & $66.60 \pm 6.97$ & 49.00 & 75.00 & $133.53 \pm 23.52$ & 103.00 & 208.00 \\
\hline İstatistiksel Analiz & \multicolumn{3}{|c|}{$K W=0.959 p=, 386$} & \multicolumn{3}{|c|}{$K W=0.312 \quad p=, 733$} \\
\hline \multicolumn{7}{|l|}{ Nargileyi içme sıklığı } \\
\hline Her gün & $64.88 \pm 8.44$ & 51.00 & 73.00 & $129.11 \pm 11.55$ & 117.00 & 158.00 \\
\hline Haftada birkaç kez & $65.90 \pm 8.09$ & 45.00 & 71.00 & $131.19 \pm 34.28$ & 86.00 & 206.00 \\
\hline Ayda birkaç kez & $66.53 \pm 7.38$ & 52.00 & 75.00 & $138.89 \pm 24.81$ & 89.00 & 208.00 \\
\hline Yılda birkaç kez & $62.54 \pm 11.31$ & 35.00 & 75.00 & $127.69 \pm 27.59$ & 93.00 & 199.00 \\
\hline İstatistiksel Analiz & \multicolumn{3}{|c|}{$K W=1.082 p=, 361$} & \multicolumn{3}{|c|}{$K W=4.898 \quad p=, 772$} \\
\hline \multirow{2}{*}{\multicolumn{7}{|c|}{$\begin{array}{l}\text { Nargileye Yönelik } \\
\text { Düşünceleri } \\
\text { Narailenin saălıăa zararı konusundaki düsüncesi }\end{array}$}} \\
\hline & & & & & & \\
\hline Zararlıdır & & 35.00 & 75.00 & $127.81 \pm 24.45$ & 67.00 & 208.00 \\
\hline Zararsızdır & $55.14 \pm 5.72$ & 45.00 & 60.00 & $112.28 \pm 16.78$ & 88.00 & 143.00 \\
\hline \multirow{2}{*}{$\begin{array}{l}\text { Bilgim yok } \\
\text { İstatistiksel Analiz }\end{array}$} & \multirow{2}{*}{\multicolumn{3}{|c|}{\begin{tabular}{c|c|c}
$61.67 \pm 9.15$ & 44.00 & 75.00 \\
$K W=13.569 \quad p=, 001$
\end{tabular}}} & \multirow{2}{*}{\multicolumn{3}{|c|}{$\mathrm{KW}=2.390 ; p=, 093$}} \\
\hline & & & & & & \\
\hline \multicolumn{7}{|c|}{ Nargile ve sigaranın insan sağlığına zararları konusundaki düşünce } \\
\hline Nargile zararsızdır & $65.30 \pm 11.4$ & 45.00 & 75.00 & $136.15 \pm 29.31$ & 88.00 & 66.00 \\
\hline Sigaradan zararsızdır & $63.96 \pm 10.0$ & 35.00 & 75.00 & $123.03 \pm 23.48$ & 83.00 & 195.00 \\
\hline Eşit derecede zararlıdır & $65.46 \pm 7.9$ & 43.00 & 75.00 & $125.21 \pm 23.70$ & 67.00 & 208.00 \\
\hline Nargile daha zararlıdır & $67.46 \pm 6.9$ & 41.00 & 75.00 & $129.15 \pm 24.31$ & 77.00 & 206.00 \\
\hline İstatistiksel Analiz & $\mathrm{KW}=$ & $4.444 p=, 0$ & & $K W=2$ & $90 p=, 08$ & \\
\hline Nargile ve bulaşıcı $h$ & onusundaki c & işünce & & & & \\
\hline Hastalık bulaştırır & $67.13 \pm 7.5$ & 35.00 & 75.00 & $128.29 \pm 24.73$ & 77.00 & 208.00 \\
\hline Hastalık bulaştırmaz & $61.10 \pm 9.7$ & 43.00 & 75.00 & $122.00 \pm 17.78$ & 92.00 & 161.00 \\
\hline Bilgim yok & $63.46 \pm 7.9$ & 43.00 & 75.00 & $122.53 \pm 23.39$ & 67.00 & 199.00 \\
\hline İstatistiksel Analiz & $\mathrm{KW}=$ & $5.175 p=, 0$ & & $K W=2$ & $380 p=, 09$ & \\
\hline Nargilenin zararları $r$ & «ında daha önce b & gi alma dur & umu & & & \\
\hline Evet & $67.59 \pm 7.1$ & 43.00 & 75.00 & $129.35 \pm 25.33$ & 83.00 & 208.00 \\
\hline Hayır & $65.00 \pm 8.4$ & 35.00 & 75.00 & $125.11 \pm 22.90$ & 67.00 & 199.00 \\
\hline İstatistiksel Analiz & $\mathrm{MW}=$ & $324 ; p=, 0$ & & $\mathrm{MW}=4$. & $p=, 04$ & \\
\hline
\end{tabular}

KW: Kruskal Wallis Testi; MW: Manny Whitney U Testi; SS= Standart Sapma; Min: En Küçük Değer; Max: En Yüksek Değer; $\bar{x}$ : Aritmetik Ortalama

Nargilenin sağlığa zararlı olduğunu düşünenlerin nargilenin sağlığa zararsız olduğunu düşünenlere ve sağlığa zararı konusunda bilgisi olmayanlara göre, nargilenin sigaradan daha zararlı olduğunu düşünenlerin nargilenin zararsız, sigaradan daha zararsız ve nargilenin sigara ile eşit derecede zararlı olduğunu düşünenlere göre, nargilenin hastalık bulaştırdığını düşünenlerin hastalık bulaştırmadığını düşünenlere ve 
bu konuda bilgisi olmayanlara göre, nargilenin zararları hakkında daha önce bilgi alanların daha önce bilgi almayanlara göre nargilenin sağlığa etkileri algılarının daha yüksek olduğu belirlendi $(p<0.05)$. Nargilenin zararları hakkında daha önce bilgi alan sağlık çalışanlarının daha önce bilgi almayan sağık çalışanlarına göre SYBDÖ-II toplam puan ortalamalarının daha yüksek olduğu saptandı ( $<<0.05)$ (Tablo 4).

\section{Tablo 5. Sağık çalısanlarının nargile kullanma durumları için risk faktörlerinin lojistik regresyon} analizi

\begin{tabular}{|c|c|c|c|c|c|c|c|c|}
\hline Bağımsız Değlşkenler & B & S.E. & Wald & df & Sig. & $\operatorname{Exp}(B)$ & \multicolumn{2}{|c|}{$\begin{array}{c}95 \% \text { Güven } \\
\text { Aralığı Exp(B) }\end{array}$} \\
\hline & & & & & & & Alt & Üst \\
\hline Yaşı & 0.037 & 0.023 & 2.429 & 1 & 119 & 1.037 & 0.991 & 1.086 \\
\hline Cinsiyeti & 0.810 & 0.245 & 10.936 & 1 & ,001 & 0.445 & 0.275 & 0.719 \\
\hline Eğitim durumu & -0.021 & 0.091 & 0.056 & 1 & 813 & 0.979 & 0.820 & 1.169 \\
\hline Ekonomik durumu & 0.069 & 0.195 & 0.126 & 1 & ,723 & 1.072 & 0.731 & 1.570 \\
\hline Çocuk sahibi olma & 0.267 & 0.168 & 2.513 & 1 & 113 & 1.306 & 0.939 & 1.817 \\
\hline $\begin{array}{l}\text { Tanılanmış hastalık } \\
\text { durumu }\end{array}$ & 0.362 & 0.356 & 1.033 & 1 & 309 & 1.436 & 0.715 & 2.882 \\
\hline Medeni durum & 0.190 & 0.307 & 0.382 & 1 & ,536 & 1.209 & 0.663 & 2.206 \\
\hline Sigara içme durumu & 0.410 & 0.193 & 4.527 & 1 & 033 & 1.507 & 1.033 & 2.198 \\
\hline $\begin{array}{l}\text { Nargilenin sağlığa } \\
\text { etkileri konusundaki } \\
\text { düşünce }\end{array}$ & -0.042 & 0.275 & 0.024 & 1 & 877 & 0.958 & 0.559 & 1.643 \\
\hline $\begin{array}{l}\text { Nargilenin bağımlılık } \\
\text { yapması konusundaki } \\
\text { düşünce }\end{array}$ & -0.167 & 0.166 & 1.020 & 1 & ,313 & 0.846 & 0.612 & 1.170 \\
\hline $\begin{array}{l}\text { Nargilenin bulaşıcı } \\
\text { hastalık yapması } \\
\text { konusundaki düşünce }\end{array}$ & 0.363 & 0.223 & 2.651 & 1 & 103 & 1.437 & 0.929 & 2.225 \\
\hline NSEAÖ & 0.024 & 0.013 & 3.474 & 1 & ,062 & 1.025 & 0.999 & 1.051 \\
\hline SYBDÖ & -0.015 & 0.005 & 8.965 & 1 & ,003 & 0.985 & 0.975 & 0.995 \\
\hline Sabit & & & & 1 & & & & \\
\hline
\end{tabular}

B: Regresyon katsayıII, SE: Standart hata, Wald: Kikare değeri, df: serbestlik derecesi, p: Anlamlılık düzeyi $(p<0.05)$, Exp (B): Odds oranı (OR)

Lojistik regresyon analizine göre, halen sigara içen sağlık çalışanlarının nargile içme olasılığı sigara içmeyen sağlık çalışanlarına göre (odds oranını) 1.507 kat (\%95 GA: 1.033-2.198), erkek sağlık çalışanının nargile içme olasilığı ise kadın sağlık çalışanlarına göre 2.247 kat (1/ 0.445) fazla olduğu saptandı. SYBDÖ-II toplam puan ortalamalarında bir birimlik puan artışının sağlık çalışanlarının nargile içme olasilığını \%1.5 [(1-0,985)*100)] oranında düşürdüğü belirlendi (Tablo 5).

\section{Tartışma}

Literatür bilgileri, sağlık çalışanları da dahil toplumda nargile kullanımının azımsanmayacak sıklıkta olduğunu ortaya koymaktadır $(9,18)$. Bu araştırma, sağlık çalışanlarının nargile içme profillerini, nargilenin sağlığa olan etkilerine yönelik algılarını ve sağlıkı yaşam biçimi davranışlarını belirlemek amacıyla yapılmıştır. Araştırmaya katılan sağlık çalışanlarının NSEAÖ'den aldıkları puan ortalamasının $66.29 \pm 7.93$ puan olarak iyi düzeyde olduğu belirlenmiştir. Aynı ölçekle yapılan diğer çalışmalarda katılımcıların

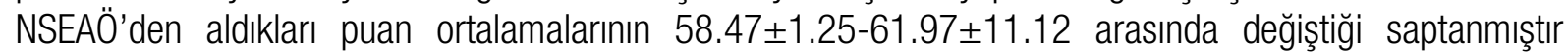
$(12,21,34)$. Araştırmada sağlık çalışanlarından elde edilen nargilenin sağıı̆a olan etkileri algı düzeyinin, 
literatürde yer alan çalışmalarda elde edilen algı düzeylerinden daha yüksek olmasının, bu araştırmanın katılımcılarının tümüyle sağlık çalışanlarından oluşması ile ilişkili olduğu düşünülmektedir.

Araştırmaya katılan sağlık çalışanlarının SYBDÖ'den aldıkları puan ortalamasının 127.22+24.21 puan olarak orta düzeyde olduğu belirlenmiştir. Öğretim elemanları ve sağlık çalışanları ile yürütülen ve aynı ölçeğin kullanıldığı diğer çalışmalarda SYBDÖ puan ortalamalarının 121.85 $\pm 18.05-128.74 \pm 18.24$ arasında değiştiği bulunmuştur (35-37). Kaya ve arkadaşlarının öğretim elemanları ile yaptığı çalışmada ise SYBDÖ puan ortalaması 139.5 \pm 18.0 olarak saptanmıştır (38). Araștırmada SYBDÖ puanı ortalamasının Kaya ve arkadaşlarının çalışmasındaki ortalamanın altında olmakla birlikte literatürdeki çoğu çalışmada elde edilen ortalama puanlara yakın olduğu görülmektedir. Aldıkları eğitimin gereği olarak, sağlık çalışanlarının sağlıklı yaşam biçimi davranışlarının özellikle toplumdaki farklı grupların sağlıklı yaşam biçimi davranışlarından daha iyi düzeyde olması beklenmektedir. Araştırma bulgusu, sağlık çalışanlarının eğitim müfredatlarında ve hizmet içi eğitimlerinde sağlığı geliştirme konularına daha fazla ağırlık verilmesi gerektiğini düşündürmektedir.

Araştırmada yer alan sağlık çalışanlarının \%17.3'ünün nargile kullandığı, yarıdan fazlasının nargile içmeye yönelmesinde arkadaş çevresinin etkisinin olduğu saptanmıştır. Nargile kullananların çoğunun nargileyi nargile kafelerde içtiği bulunmuştur. Türkiye'de genç yetişkin yaş olarak kabul edilen sağık alanında okuyan üniversite öğrencilerine yönelik yapılan çalışmalarda nargile içme prevalansının \%12.2 ila \%34.0 arasında olduğu saptanmıştır (20-23,30-31). Ülke dışında sağlık alanında okuyan üniversite öğrencilerine yönelik yapılan çalışmalarda nargile kullanma sıkığının \%12.6-23 arasında olduğu bulunmuştur $(39,40)$. Sağlık çalışanlarına yönelik yürütülen bir çalışmada, tütün ürünleri kullananların \%38'inin nargile ve sigarayı birlikte kullandıkları bulunmuştur (24). Sağlık çalışanlarıyla yürütülen başka bir çalışmada, sigara dışında herhangi bir tütün ürünü kullananların büyük çoğunluğunun nargile kullandığı ortaya çıkmıştır (25). Yapılan bir başka çalışmada, hemşirelerin \%28.4'ünün nargile içtiği belirlenmiştir (26). Araştırmada elde edilen nargile kullanma sıklığının yurt içindeki ve yurt dıșındaki nargile kullanma prevalans aralığında yer aldığı, ancak sağlık çalışanları ile yürütülen diğer çalışmalarda elde edilen nargile kullanım sıklığından daha düşük olduğu görülmektedir. Literatürde yer alan birçok çalışmada nargilenin daha çok nargile kafelerde kullanıldığı $(21,41-43)$ ve arkadaş çevresinin ve sosyal ortamların nargile kullanımında etkili olduğu belirlenmiştir (20,44-49). Nargile kullanımında arkadaş çevresinin etkili olduğuna, daha çok nargile kafelerde nargile kullanıldığına ilişkin literatür bulguları, araştırma sonuçlarını destekler niteliktedir. Nargile ya da sigara içen arkadaşı bulunan erişkinlerin nargile içme davranışını daha çok gösterdikleri saptanmıştır $(50,51)$. Yapılan çalışmalar nargile kafelerin çoğalmasının nargile kullanımındaki artışla ilişkili olduğunu ortaya koymaktadır. Çoğunluğu 20-35 yaş arasında olan katıımcılardan oluşan bu araştırmada olduğu gibi, günümüzde gençlerin nargile kullanım alanları genellikle nargile kafelerdir. Kafelerin yaygınlığı ve ulaşım kolaylığı bundan sonraki dönemlerde yeni tehlikelerin sinyalleri olabilir.

Araştırmaya katılan sağlık çalışanlarının yarıdan fazlasının nargileyi sigaradan daha zararlı buldukları, çoğunluğunun nargilenin zararlı olduğunu, bağımlılık yaptığını ve nargilenin hastalık bulaştırdığını düşündüğü bulunmuştur. Araştırma bulgularının aksine, yapılan çalışmalarda, nargilenin sigaraya göre daha az zararlı algılandığı sonucuna ulaşımıştır $(8,21,47,52-54)$. Nargilenin sigaradan daha az zararlı olduğu düşüncesinin, nargilenin sudan geçirildiği için zararlı maddelerinin engellendiği şeklindeki algıdan kaynaklandığını bildiren çalışmalar bulunmaktadır $(55,56)$. Araştırma bulgularıyla tutarlı olarak, Deckers ve arkadaşlarının pediatri hemşirelerinin tütün ve nargile kullanımını belirlemeye yönelik yaptıkları çalışmada hemşirelerin nargilenin zararlarına dair bilgilerinin olduğu ve kullanımlarının düşük düzeyde olduğu bulunmuştur (57). Katılımcıların yarısının nargilenin sigaradan daha zararlı olduğuna ve çoğunluğunun nargilenin zararlı olduğunu düşünmesine ilişkin araştırma bulgusu, sağlık çalışanı olan hemşirelerle yürütülen Deckers ve arkadaşlarının çalışma bulguları dışında, nargilenin sigaradan daha az zararlı olduğuna ilişkin çoğu literatür bulgusundan farklıdır. Bu farklılığın araştırmadaki örneklem grubunun sağlık çalışanlarından oluşması ve sağık ile ilgili bilgi düzeylerinin olağan olarak daha yüksek olması ile ilişkili olduğu düşünülmektedir. 
Araştırmanın sonucunda, eğitim düzeyi lisansüstü olan, erkek, geliri giderden fazla olan ve her gün sigara içen sağlık çalışanlarında nargile kullanımının daha yüksek olduğu belirlenmiştir. Yürütülen iki çalışmada, eğitim düzeyi ile nargile kullanımı arasında anlamlı bir ilişki bulunmamışıı $(55,58)$. Araştırma bulgusu, bu yönüyle literatürden farkklık göstermektedir. Bunun nedeninin, araştırmadaki örneklem grubunun daha yüksek eğitim düzeyli sağık çalışanlarından, diğer çalışmalardaki örneklem gruplarının ise öğrencilerden oluşmuş olmasından kaynaklandığı düşünülmektedir. Araştırma bulgularına paralel olarak, yapılan diğer çalışmalarda ekonomik düzey yükseldikçe nargile kullanma sıklığının arttığı saptanmıştır $(7,18,21,59,60)$. Ekonomik düzey yükseldikçe nargile içme sıkığının artmasının, bireylerin sosyal yapısı ile ilişkili olabileceği düşünülmektedir. Bu yönüyle literatür sonuçları birbirine benzerlik göstermektedir ve ekonomik düzeyi yüksek olan sağlık çalışanları için nargilenin ulaşılabilirliği daha kolaydır.

Araştırmada yapılan lojistik regresyon analizine göre erkek sağlık çalışanlarında nargile içme olasılığı 2.247 kat fazla bulunmuştur. Diğer birçok çalışmada da erkeklerde nargile kullanımının kadınlara göre daha sık olduğu saptanmıştır (20,60-64). Literatür bulguları, araştırmada erkek sağlık çalışanlarının kadın sağlık çalışanlarından daha fazla nargile kullandığına ilişkin bulguyu desteklemektedir. Araştırma ve literatür bulguları tütün ve tütün ürünleri kullanımının, beklendik bir sonuç olarak daha çok erkeklerin sergilediği davranış olduğunu ortaya koymaktadır.

Araştırmada yapılan lojistik regresyon analizine göre sağlık çalışanlarının halen sigara içiyor olmalarının nargile içme olasıı̆ğını 1.507 kat artırdığı bulunmuştur. Yapılan birçok çalışma, sigara içme ile nargile içme arasında anlamlı bir ilişki olduğunu gösteren araştırma bulgusunu destekler niteliktedir ve sigara içme davranışının nargile içme davranışını etkilediğini ortaya koymaktadır $(20,26,31,47,49,55,65-68)$. Bu bağlamda, sigara içme davranışının nargile kullanımı için bir geçiş aracı olabildiği söylenebilir.

Araştırmada kadın sağık çalışanlarının erkek sağlık çalışanlarına, geniş ailede olanların diğer aile tiplerine göre nargilenin sağlığa etkileri algılarının daha yüksek olduğu belirlenmiştir. Yapılan birçok çalışmada da kadın katılımcıların nargilenin sağlığa etkileri algılarının erkeklere nazaran daha yüksek olduğu saptanmıştır $(7,12,21,34,69)$. Literatür bulguları araştırma sonuçlarıyla paralellik göstermektedir. Nargilenin sağlığa etkileri algısının kadınlarda erkeklerden daha yüksek olması, kadınların sağlıklarına daha fazla dikkat etmeleri ve risk alma eğilimlerinin erkeklere göre daha az olması, sorumluluk duygusu ile açıklanabilir. Salloum ve arkadaşlarının Amerika'da yürüttükleri çalışmada gençlerin nargile kullanımının aile yapısıyla ilişkili olduğu saptanmıştır (67). Bu araştırmada da benzer sonuçlar elde edilmiştir. Nitekim parçalanmış ailede yetişen bireylerin nargilenin sağlığa etkileri konusunda algılarının daha düşük olduğu bulunmuştur. Bununla birlikte yapılan iki çalışmada, araştırma bulgularından farklı olarak aile tipi ile nargilenin sağlığa etkisi algıları arasında anlamlı ilişki bulunmamıştır $(21,58)$. Bulgulardaki bu farklıı̆ın, yapılan çalışmaların farklı örneklem gruplarılla yürütülmesinden kaynaklanabileceği düşünülmektedir.

Araştırmada nargile içmeyen sağlık çalışanlarının nargile içen ve nargileyi bırakmış olan sağlık çalışanlarına göre nargilenin sağlığa etkileri algılarının daha yüksek olduğu belirlenmiştir. Algı yüksekliğine ilişkin bu bulgu, sağlık çalışanlarının bağımılıık yapıcı madde kullanımına yönelik eğitim almış ve bilinçlenmiş olmaları ile açıklanabilir. Benzer şekilde yapılan başka çalışmalarda da nargile ve tütün ürünü kullanmayanların nargilenin sağlığa etkileri ile ilgili algılarının yüksek olduğu bulunmuştur $(12,70,71)$. Araştırma sonuçları literatür ile uyumludur. Bu noktadan hareketle, nargilenin sağlığa zarar verici etkilerini yüksek düzeyde algılayan kişilerin, nargilenin sağlığa zarar verici etkilerini düşük düzeyde algılayan kişilere göre nargile kullanma davranışından daha fazla kaçınma eğilimi gösterecekleri söylenebilir.

Araştırmaya katılan sağlık çalışanlarının NSEAÖ ile SYBDÖ arasında pozitif yönde anlamlı bir ilişki olduğu, sağlık çalışanlarının nargilenin sağlığa etkileri algısının yükselmesiyle, sağlıklı yaşam biçimi davranışlarının arttığı saptanmıştır. Yapılan lojistik regresyon analizine göre sağlıklı yaşam biçimi davranışları ölçeği puan ortalamalarındaki bir birimlik puan artışının sağlık çalışanlarının nargile içme olasılığını \%1.5 oranında düşürdüğü belirlenmiştir. Literatürde NSEAÖ ve SYBDÖ arasındaki ilişkiyi doğrudan ele alan bir çalışmaya rastlanmamakla birlikte Zengin ve Çınar'ın çalışmasında, ergenlerin nargilenin sağlığa etkileri ile ilgili algıları arttıkça riskli davranışlara eğilimlerinin azaldığına ilişkin elde ettikleri bulgu, araştırma bulgularını destekler niteliktedir (71). Araştırmadan elde edilen bu bulgu değerlendirildiğinde, sağlıkı yaşam biçimi 
davranışlarını daha fazla sergileyen sağlık çalışanlarının sağlığa zarar veren maddelere ilişkin zarar algısının da daha yüksek olmasının beklenen bir durum olduğu söylenebilir.

Araştırmanın bir il merkezindeki hastanelerde görevli sağlık çalışanları ile yürütülmüş olması ve sağlık çalışanlarının nargile kullanma durumlarının sadece kendi bildirimlerine dayalı olması çalışmanın sınırıııkları olarak ifade edilebilir.

Araştırmada nargile kullanan sağlık çalışanlarının nargilenin sağlığa etkileri algılarının nargile kullanmayan sağlık çalışanlarından düşük olduğu, nargilenin sağlığa etkileri algıları daha yüksek olan sağlık çalışanlarının ise sağlıklı yaşam biçimi davranışlarını daha fazla gösterdiği tespit edilmiştir. Bu sonuçlar, nargile içmenin dolayısıyla sağlıksız yaşam biçimi davranışları sergilemenin nargilenin sağlığa etkileri algılarıı olumsuz yönde etkilediğini ortaya koymuştur. Son yıllarda artış gösteren nargile kullanımına dair toplumda oluşan yanlış bilgilerin giderilmesi ve nargile kullanımının önüne geçilmesi gerekmektedir. Bu doğrultuda özellikle sağlık çalışanlarından başlayarak toplumun her kesimine yönelik eğitim programlarının hazırlanması, tütün ve tütün ürünleri kullanımına karşı verilebilecek en güzel mücadeledir. Özellikle toplumu bilgilendirme ve bilinçlendirme rolleri ön planda olan hemşirelerin eğitimlerine tütün kontrolü dahil edilmeli ve bu konu üzerine yoğunlaşılmalıdır.

\section{Kaynaklar}

1. Drope J, Schluger N, Cahn Z, et al. The Tobacco Atlas. Atlanta: American Cancer Society and Vital Strategies, 2018.

2. World Health Organization (WHO). The history of tobacco. 2020. Available from: https://www.who.int/tobacco/en/atlas2.pdf/ (Accessed date: 16.06.2020)

3. Çağlak U. Boş zaman alışkanlıklarında nostaljik bir trend: yeni nargile kültürü ve nargile mekânları. Uluslararası Sosyal Bilimler Dergisi 2018; 2(13): 67-83.

4. Dağlı Z, Demirezen D. Kamu politikası bağlamında nargile kullanımı üzerine bir değerlendirme. Uluslararası Yönetim Iktisat ve Isşletme Dergisi 2020; 16(2): 310-325.

5. Durmuş A, Teber M, Akyılmaz D, et al. (Editörler). Nargile kullanımı ve zararları. Türkive bağımlııkla mücadele eğitim programı-yetişkin "Sigara vücudun düşmanı" Kitabı. İstanbul: Türkiye Yeşilay Cemiyeti TBM Alan Kitaplığı Dizisi: 8, 2016; 10.

6. Özkan-Sarılı S. Nargile kullanımında riskler, tehditler ve önleyici yaklaşımlar. Sağlık Bilimlerinde Illeri Araştırmalar Dergisi 2019; 2(3): 105-114.

7. Özcebe H, Doğan BG, İnal E, et al. Üniversite öğrencilerinin nargile içme davranışları ve ilişkili sosyodemografik özellikleri. TAF Preventive Medicine Bulletin 2014; 13(1): 19-28.

8. Ozouni-Davaji RB, Dadban-Shahamat $Y$, Hajili-Davaji $F$, et al. Patterns, beliefs, norms and perceived harms of hookah smoking in North Iran. Asian Pac J Cancer Prev 2017; 18(3): 823-830.

9. Heinz AJ, Giedgowd GE, Crane NA, et al. A comprehensive examination of hookah smoking in college students: use patterns and contexts, social norms and attitudes, harm perception, psychological correlates and cooccurring substance use. Addict Behav 2013; 38(11): 2751-2760.

10. Braun RE, Glassman T, Wohlwend J, et al. Hookah use among college students from a Midwest University. J Community Health 2012; 37(2): 294-298.

11. Ali M, Jawad M. Health effects of waterpipe tobacco use: getting the public health message just right. Tob Use Insights 2017; 10: 1-8.

12. Cakmak V, Cinar N. Turkish adolescent perceptions about the effects of water pipe smoking on their health. Asian Pac J Cancer Prev 2014; 16(18): 8645-8652.

13. Kocataş $S$, Güler N. Nargile-aromatik nargile kullanımı. Kocataş S, Güler N (Editör). Tüm Boyutlarıyla Tütün Bağımllı̆ğı Kitabı. Sivas: Sivas Cumhuriyet Üniversitesi Sağlık Bilimleri Fakültesi Yayın No: 1, 2019; 99-110.

14. Asma S, Gereklioglu C, Korur A, Solmaz S. Waterpipe smoking: an incidios threat for the young. J Family Med Prim Care 2016; 10(2): 91-95.

15. Grinberg A, Goodwin RD. Prevalence and correlates of hookah use: a nationally representative sample of US adults ages 18-40 years old. Am J Drug Alcohol Abuse 2016; 42(5): 567-576.

16. Jawad M, Lee JT, Millett C. Waterpipe tobacco smoking prevalence and correlates in 25 Eastern Mediterranean and Eastern European Countries: cross-sectional analysis of the Global Youth Tobacco Survey. Nicotine Tob Res 2016; 18(4): 395-402. 


\section{Bağımlılık Dergisi - Journal of Dependence}

17. Dar-Odeh NS, Bakri FG, Al-Omiri MK, et al. Narghile (water pipe) smoking among university students in Jordan: prevalence, pattern and beliefs. Harm Reduct J 2010; 7: 10.

18. Grant A, Morrison R, Dockrell MJ. Prevalence of waterpipe (shisha, narghille, hookah) use among adults in Great Britain and factors associated with waterpipe use: data from cross-sectional online surveys in 2012 and 2013. Nicotine Tob Res 2014; 16(7): 931-938.

19. Küresel Yetişkin Tütün Araştırması Türkiye Raporu. Sağlık Bakanlığı Temel Sağlık Hizmetleri Genel Müdürlüğü, 2010.

20. Aktaş A, Hıdıroğlu S, Karavuş M. Üniversite öğrencilerinin nargile içme konusundaki bilgi, tutum ve davranışları. Firat Tip Dergisi 2018; 23(2): 68-72.

21. Cevik BE, Kocatas S. Hookah smoking profiles of university students and their perceptions of its health risks. Addicta: The Turkish Journal on Addictions 2020; 7(3): 206-213.

22. Korkmaz M, Ersoy S, Özkahraman Ş, et al. Süleyman Demirel Üniversitesi öğrencilerinin tütün mamulleri alkol kullanım durumları ve sigaraya yaklaşımları. Süleyman Demirel Üniversitesi Tıp Fakültesi Dergisi 2013; 20(2): 34-42.

23. Poyrazoglu S, Sarlı S, Gencer Z, Günay 0. Waterpipe (narghile) smoking among medical and non-medical university students in Turkey. Upsala J Med Sci 2010; 115: 210-216.

24. Çilekar Ş, Günay E, Burhan HS, Özalp N, Sansar B, Ertürk S, Kıran M, Çakır E, Erdoğan B. Hastanemizde sağlık çalışanlarının tütün ürünlerini kullanma durumu. Kocatepe Tıp Dergisi 2020; 21: 295-300.

25. Ağırman E, Gençer MZ, Arıca S. Sağık çalışanlarının kanseri önlemeye yönelik bilgi, tutum ve davranışları. Journal of Health Science and Profession 2019; 6(2): 220-227.

26. Sezgin L, Pirinçci E. Muş ili ve ilçelerindeki hastanelerde görev yapan hemşirelerin sigara içme durumlarının değerlendirilmesi. Kahramanmaraş Sütçü Imam Üniversitesi Tıp Fakültesi Dergisi 2020; 15(3): 14-21.

27. Ayaz S, Tezcan S, Akıncı F. Hemşirelik Yüksekokulu öğrencilerinin sağlığı geliştirme davranışları. Cumhuriyet Üniversitesi Hemşirelik Yüksekokulu Dergisi 2005; 9(2): 26-34.

28. Bahar Z, Açı D. Sağlığı geliştirme modeli: kavramsal yapı. Dokuz Eylül Üniversitesi Hemşirelik Fakültesi Elektronik Dergisi 2014; 7(1): 59-67.

29. Ezer S. Sağlık çalışanlarının sağlıklı yaşam biçimi davranışları ile profesyonel yaşam kaliteleri arasındaki ilişkinin ve etkileyen faktörlerin incelenmesi. Yüksek Lisans Tezi, İstanbul: Üsküdar Üniversitesi Sağllk Bilimleri Enstitüsü, Hemşirelik ABD, 2018.

30. Koca B, Oğuzöncül AF. İnönü Üniversitesi Sağlık Yüksekokulu öğrencilerinin sigara, alkol, madde kullanımı, madde kullanımına etki eden etmenler ve aileden aldıkları sosyal desteğin etkisi. Kocaeli Tıp Dergisi 2015; 4(2): 4-13.

31. Kuş C, Gümüştakım RŞ, Erylmaz ME. Kahramanmaraş Sütçü İmam Üniversitesi Tıp Fakültesi öğrencilerinin tütün ve tütün ürünleri kullanma durumu ve ilişkili faktörler. Adddicta: The Turkish Journal on Addictions 2019; 6(4): 182-193.

32. Bahar Z, Beşer A, Gördes N, et al. Sağlıklı Yaşam Biçimi Davranışları Ölçeği Il'nin geçerlilik ve güvenirlik çalışması. Cumhuriyet Üniversitesi Hemşirelik Yüksekokulu Dergisi 2008; 12(1): 1-13.

33. Kolaç N, Sezer-Balcı A, Şişman FN, et al. Fabrika çalışanlarında sağlıkı yaşam biçimi davranışı ve sağlık algısı. Bakırköy Tıp Dergisi 2018; 14(3): 267-274.

34. Zengin H. Ergenlerin risk alma davranışları ile nargilenin sağlı̆a etkilerine yönelik algılarının incelenmesi. Yüksek Lisans Tezi, Sakarya: Sakarya Üniversitesi Sağlık Bilimleri Enstitüsü, Hemşirelik ABD, 2015.

35. Yalçınkaya M, Özer FG, Karamanoğlu AY. Sağlık çalışanlarında sağlıklı yaşam biçimi davranışlarının değerlendirilmesi. TSK Koruyucu Hekimlik Bülteni 2007; 6(6): 409-420.

36. Özkan S, Yılmaz E. Hastanede çalışan hemşirelerin sağlıkı yaşam biçimi davranışları. Fırat Sağılık Hizmetleri Dergisi 2008; 3(7): 89-105.

37. Güler G, Güler N, Kocataş S, et al. Bir üniversitede çalışan öğretim elemanlarının sağlıklı yaşam biçimi davranışları. Cumhuriyet Üniversitesi Hemşirelik Yüksekokulu Dergisi 2008; 12(3): 18-26.

38. Kaya F, Ünüvar R, Bıçak A, et al. Öğretim elemanlarının sağlığı geliştirme davranışları ve etkileyen etmenlerin incelenmesi. TSK Koruyucu Hekimlik Bülteni 2008; 7(1): 59-64.

39. Salameh P, Salame J, Waked M, et al. Waterpipe dependence in university students and effect of normative beliefs: a cross-sectional study. BMJ Open 2014; 4(2): e004378.

40. Taha AZ, Sabra AA, Al-Mustafa ZZ, et al. Water pipe (shisha) smoking among male students of medical colleges in the eastern region of Saudi Arabia. Ann Saudi Med 2010; 30(3): 222-226.

41. Mugyenyi AEK, Haberer JE, O'Neil I. Pleasure and practice: a qualitative study of the individual and social underpinnings of shisha use in cafes among youth in the UK. BMJ 2018; 8: 018989. 
42. Robinson JN, Wang B, Jackson KJ, et al. Characteristics of hookah tobacco smoking sessions and correlates of use frequency among US adults: findings from wave 1 of the population assessment of tobacco and health (PATH) study. Nicotine Tob Res 2018; 20(6): 731-740.

43. Danaei M, Jabbarinejad-Kermani A, Mohebbi E, Momeni M. Waterpipe tobacco smoking prevalence and associated factors in the southeast of Iran. Addict Health 2017; 9(2): 72-80.

44. Çevik-Akyıl R, Kahraman A, Erdem N. Üniversite öğrencilerinin nargile kullanımıı etkileyen faktörlerin belirlenmesi. İzmir Göğüs Hastanesi Dergisi 2018; 22(3): 177-184.

45. Dadipoor S, Kok G, Aghamolaei T, et al. Explaining the determinants of hookah consumption among women in southern Iran: a qualitative study. BMC Public Health 2019; 19: 1655.

46. Singh T, Arrazola RA, Corey CG, et al. Tobacco use among middle and high school students-United States, 2011-2015. MMWR Morb Mortal Wkly Rep 2016; 65(14): 361-367.

47. Maziak W, Fouad FM, Asfar T, et al. Prevalence and characteristics of narghile smoking among university students in Syria. Int J Tuberc Lung Dis 2004; 8(7): 882-889.

48. Veeranki SP, Alzyoud S, Dierking L, et al. Associations of adolescents' cigarette, waterpipe, and dual tobacco use with parental tobacco use. Nicotine Tob Res 2016; 18(5): 879-884.

49. Sezer RE, Tanrı̈̈ver Ö, Dirimen-Arıkan G, Kaçar M. Üniversite öğrencilerinde nargile odaklı tütün ürünleri kullanımı ve illk denenen tütün ürünü ile tütün ürünü kullanıcısına dönüşme arasındaki ilişki. Turkish Journal of Family Medicine and Primary Care 2018; 12(4): 281-287.

50. Alzyoud S, Weglicki LS, Kheirallah KA, et al. Waterpipe smoking among middle and high school Jordanian students: patterns and predictors. Int J Environ Res Public Health 2013; 10(12): 7068-7082.

51. Shadid HM, Hossain SZ. Understanding smoking behaviour among secondary school students in Amman, Jordan: a qualitative study. J Community Med Health Educ 2013; 3: 199.

52. Roditis M, Delucchi K, Cash D, Halpern-Felsher B. Adolescents' perceptions of health risks, social risks, and benefits differ across tobacco products. J Adolesc Health 2016; 58(5): 558-566.

53. Alvur MT, Cinar N, Akduran F, Dede C. Fallacies about water pipe use in Turkish university students-what might be the consequences? Asian Pac J Cancer Prev 2014; 15(5): 1977-1980.

54. Aboaziza E, Eissenberg T. Waterpipe tobacco smoking: what is the evidence that it supports nicotine/tobacco dependence? Tob Control 2015; 24: 44-53.

55. Hassoy H, Ergin I, Davas A, et al. Sağllk Meslek Yüksek Okulu öğrencilerinde sigara, nargile, sarma tütün kullanımını etkileyen faktörlerin belirlenmesi ve öğrencilerin sigara, nargile, sarma tütüne başlama ve sürdürme konusundaki görüşleri. Solunum Dergisi 2011; 13(2): 91-99.

56. Yoldaş $\mathrm{C}$, Demircioğlu H. Madde kullanımı ve bağımlılığını önlemeye yönelik psikoeğitim programlarının incelenmesi. Bağımlılık Dergisi 2020; 21(1): 72-91.

57. Deckers SK, Farley J, Heath J. Tobacco and its trendy alternatives: implications for pediatric nurses. Crit Care Nurs Clin North Am 2006; 18(1): 95-xiii.

58. Yolcu-Ağaç A. Seçilmiş bir grup ergen arasında nargile kullanım durumunun saptanması ve nargile ile ilgili algının değerlendirilmesi. Uzmanlık Tezi, Ankara: Hacettepe Üniversitesi Tıp Fakültesi, Aile Hekimliği ABD, 2020.

59. Ghelichkhani $P$, Yaseri $M$, Yousefifard $M$, et al. The gap of cigarette and hookah smoking between socioeconomic groups in Iran: effect of inequalities on socioeconomic position. Arch Iran Med 2018; 21(9): 418-424.

60. Al-Naggar RA, Saghir FSA. Water pipe (shisha) smoking and associated factors among Malaysian University students. Asian Pac J Cancer Prev 2011; 12(11): 3041-3047.

61. Baker OG, Rice V. Predictors of narghile (water-pipe) smoking in a sample of American Arab Yemeni adolescents. J Transcult Nurs 2008; 19(1): 24-32.

62. Abdullah P, Costanian C, Khanlou N, Tamim H. Prevalence and characteristics of water-pipe smoking in Canada: results from the Canadian Tobacco Use Monitoring Survey. Public Health 2017; 148: 102-108.

63. Akpınar EE, Akpınar S, Gülhan M. Üniversite öğrencilerinin tütün kullanımı ve konu ile ilgili bilgi düzeyleri. Solunum Dergisi 2010; 12(1): 1-6.

64. Sarrafzadegan N, Toghianifar N, Roohafza $\mathrm{H}$, et al. Lifestyle-related determinants of hookah and cigarette smoking in Iranian adults. Journal of Community Health 2010; 35(1): 36-42.

65. Rice VH, Weglicki LS, Templin T, et al. Predictors of Arab American adolescent tobacco use. Merrill-Palmer $Q$ (Wayne State Univ Press) 2006; 52(2): 327-342.

66. Mays D, Johnson AC, Phan L, et al. Effect of risk messages on risk appraisals, attitudes, ambivalence, and willingness to smoke hookah in young adults. Health Psychol Behav Med 2020; 8(1): 96-109. 


\section{Bağımlılık Dergisi - Journal of Dependence}

67. Salloum RG, Haider MR, Barnett TE, et al. Waterpipe tobacco smoking and susceptibility to cigarette smoking among young adults in the United States, 2012-2013. Prev Chronic Dis 2016; 13: E24.

68. Wong LP, Alias H, Aghamohammadi N, et al. Shisha smoking practices, use reasons, attitudes, health effects and intentions to quit among shisha smokers in Malaysia. Int J Environ Res Public Health 2016; 13(7): 726.

69. Paksoy-Erbaydar N, Bilir N, Yıldı AN. Knowledge, behaviors and health hazard perception among Turkish narghile (waterpipe)-smokers related to narghile smoking. Pak J Med Sci 2010; 26(1): 195-200.

70. Camenga DR, Delmerico J, Kong G, et al. Trends in use of electronic nicotine delivery systems by adolescents. Addict Behav 2014; 39(1): 338-340.

71. Zengin $\mathrm{H}, \mathrm{Cinar} \mathrm{N}$. A study on risk-taking behaviours of adolescents and their perception towards effects of hookah use on health. International Refereed Academic Journal of Sports, Health and Medical Sciences 2018; 29: 49-62. 